\title{
PERAN STRATEGIS PENDIDIKAN ISLAM DALAM MEWUJUDKAN ISLAMIC GOOD GOVERNANCE
}

\author{
AANG KUNAIFI \\ STAI Al-Khairat Pamekasan \\ akunaifi@gmail.com
}

\begin{abstract}
It's a certainly thing to applied good governance in a public interaction whole a state. Good governance is a major factor to satisfy all public needs as well as possible. But, the fact nowdays is very far from our wish. So, we need to looking for a ideal good governance model, and the alternative is Islamic Good Governance which is has a clearence as an ideology and historical efectiveness. We just need an effort to explore how to apply it contextually in a public service whole a state.Becouse Islam is perfectly an completely religion arround the world. It's very interested to known how each of public components to contribute in it, specially for to islamic educational institution. It has a vitality contibution an strategic in exploring IGG.As we know that it is medium to creat as much as possible human resources tha able to applied IGG.
\end{abstract}

\begin{abstract}
Abstrak
Penerapan good governance merupakan keniscayaan bagi interaksi masyarakat berbangsa dan bernegara. Eksistensi good governance akan menjadi faktor utama terpenuhinya hajat publik secara baik, merata, dan sempurna. Namun faktanya seperti pungguk merindukan bulan, jauh dari harapan. Oleh karena itu merumuskan model good governance yang ideal adalah langkah yang harus dilakukan. Salah satu alternatifnya adalah Islamic good governance (IGG) yang memiliki landasan ideologi yang jelas dan memiliki fakta historis akan efektivitasnya. Sehingga dibutuhkan usaha keras untuk mengeksplorasi metode menerapkan IGG dalam konteks kekinian, sehingga kesempurnaan Islam sebagai agama dan ideologi mampu teraplikasi secara baik dalam kehidupan berbangsa dan bernegara. Untuk itu menjadi menarik untuk memberikan peran yang proporsional terhadap elemen dan komponen masyarakat, salah satunya adalah institusi pendidikan Islam. Ditinjau dari tujuan dan fungsinya, institusi pendidikan Islam memiliki peran yang vital dalam mengeksplorasi IGG (reinventing Islamic good governance). Karena institusi pendidikan Islam merupakan wadah yang memiliki peran strategis bagi terciptanya SDM yang mumpuni bagi terwujudnya IGG.
\end{abstract}

Kata kunci: Islamic Good Governance (IGG), Pendidikan Islam, Peran Startegis.

\section{Pendahuluan}

Good governance merupakan cita-cita bersama sebuah entitas bangsa atau masyarakat. Sebab tujuan suatu bangsa mendirikan sebuah negara yang berdaulat 
adalah untuk tercapainya tujuan hidup mereka, yaitu pemenuhan kebutuhan jasmani dan naluri mereka, terciptanya kesejahteraan, jaminan keamanan dan terwujudnya masyarakat yang cerdas. Sebagaimana dijelaskan Dr. Ir. Rahmat Kurnia, M.Si. ${ }^{1}$, bahwa setidaknya tujuan berbangsa dan bernegara ada 4 (empat) hal antara lain: (1) Jaminan kesejahteraan bagi masyarakat secara merata, (2) Perlindungan keamanan dan ketentraman dalam masyarakat, (3) Mewujudkan kecerdasan masyarakat

Semuanya diharapkan benar-benar terealisasi melalui terciptanya good governance. Sebab interaksi dalam masyarakat dibangun berdasarkan upaya saling bekerjasama untuk memenuhi kebutuhan masing-masing. Tidak dapat dipungkiri bahwa manusia secara individu merupakan makhluk sosial yang saling bergantung dan membutuhkan. Sifat manusiawi tersebut akan terus bertahan selama manusia hidup di dunia. Wal hasil, manusia hadir di muka bumi untuk saling berinteraksi dan bekerjasama satu sama lain. Dengan demikian keberadaan good governance sesungguhnya merupakan keniscayaan yang harus diwujudkan bersama-sama.

Berdasarkan fenomena di atas, penulis menyusun artikel ini untuk memahami: Apa yang dimaksud dengan good governance? Mengapa penerapan Islamic good governance sangat dibutuhkan dalam kehidupan bernegara? Bagaimana peranan strategis pendidikan Islam dalam menciptakan Islamic good governance?

\section{Terminologi dan Aksiologi Good Governance}

Secara terminologi governance memiliki arti: rule with authority and conduct the policy, actions and affairs (of state, subjects) constitutionally; yaitu otoritas dalam mengatur dan menggerakkan kebijakan, strategi serta hubungan antara komponen dalam negara sesuai konstitusi². Sedangkan good governance menurut World Bank bisa didefinisikan sebagai suatu penyelenggaraan manajemen pembangunan yang solid dan bertanggung jawab yang sejalan dengan prinsip keterbukaan, keadilan dan pasar yang efesien, menghindari salah alokasi dana investasi, mencegah korupsi, menjalankan disiplin anggaran serta penciptaan hukum dan politik yang mendorong tumbuhnya aktivitas usaha. Sedangkan Sumarto Hetifa menjelaskan bahwa good governance adalah penyelenggaraan manajemen pembangunan yang solid dan bertanggungjawab sejalan dengan prinsip demokrasi dan pasar yang efisien, penghindaran salah alokasi dana investasi dan mencegah korupsi baik secara politik dan administratif, menjalankan disiplin anggaran serta penciptaan legal and political frame work bagi tumbuhnya aktivitas usaha. ${ }^{3}$

\footnotetext{
1 Pakar kebijakan publik dan akademisi di Institut Pertanian Bogor, disampaikan dalam acara Jakarta International Conference of Muslim Intelectual (JICMI) di Gedung SMESCO Jakarta pada tanggal 16 Januari 2013.

2 Abidari Rosidi dan Anggraeni Fajriani, Reinventing Government, (Yogyakarta: Andi Offset, 2014), 4.

3 Sumarto Hetifa, Sj, Inovasi, Partisipasi, dan Good Governance, (Bandung: Yayasan Obor Indonesia, 2003), 1-2.
} 
United Nations Economic and Social Commission for Asia and the Pacific (UNESCAP) menginformasikan tentang adanya upaya pengkerdilan definisi governance oleh beberapa pihak tertentu melalui pemaknaan hanya pada peran pemerintahan atau birokrasi, padahal governance secara kontekstual meliputi perusahaan (corporate), institusi internasional, institusi nasional, dan institusi lokal. UNESCAP mendefinisikan goernance sebagai: the process of decision-making and the process by which decisions are implemented (or not implemented). ${ }^{4}$ Yaitu sebuah proses pengambilan keputusan dan metode melaksanakannya. Bagaimana menjalan proses tersebut sebaik mungkin merupakan istilah good governance. Oleh karena itu, dalam standar UNESCAP ciri-ciri good governance dapat dijabarkan sebagai berikut:

1. Participation; yaitu keterlibatan setiap komponen dalam suatu entitas atau institusi

2. Rule of Law; yaitu memiliki kerangka kerja dan standar operasional yang jelas sehingga bisa menghindari kebijakan yang diskriminatif atau subyektif

3. Transparency; yaitu setiap keputusan yang diambil berdasarkan kerangka kerja dan standar operasional yang dapat diketahui dan dapat diakses informasi prosesnya oleh pihak-pihak yang berkepentingan

4. Responsiveness; yaitu setiap institusi dalam proses pengambilan keputusannya harus memperhatikan dan mampu melayani seluruh stakeholder dalam batasan-batasan yang rasional

5. Consensus Oriented; yaitu setiap komponen dalam institusi diharuskan menjalankan keputusan berdasarkan kesepakatan bersama atau mufakat serta menghindari adanya kepentingan-kepentingan sepihak

6. Equity and Inclusiveness; yaitu suatu keputusan mampu menjamin hak-hak setiap komponen dalam institusi sehingga mereka merasa nyaman menjalankan aktivitas dan tugas mereka

7. Effectiveness and Efficiency; melalui dukungan seluruh stakeholder suatu entitas bisnis atau institusi pelayanan publik diharapkan tercapai tujuan yang dicitacitakan atau ditargetkan dengan penggunaan sumberdaya (resources) secukupnya, sehingga suatu entitas dan institusi akan berpeluang beroperasi secara berkesinambungan (sustainable)

8. Accountability; akuntabilitas merupakan persyaratan kunci dalam menciptakan good governance. Baik pemerintah maupun swasta memerlukan jaminan akuntabilitas untuk mendapatkan kepercayaan publik. Kemampuan akuntabilitas entitas maupun institusi akan memunculkan kepercayaan publik yang akan menjadi indikator apakah entitas atau institusi tersebut layak disebut memiliki good governance atau bad governance ${ }^{5}$.

Maka, dalam sistem demokrasi idealnya penciptaan good governance harus dilakukan oleh 3 komponen antara lain; pemerintah (state), masyarakat (civil

\footnotetext{
4 Yap Kioe Sheng, Chief Poverty Reduction Section UNESCAP, www.unescap.org, diakses tanggal 11 Nopember 2015, jam 09.30 wib.

5 Yap Kioe Sheng, Chief Poverty Reduction Section UNESCAP, www.unescap.org, diakses tanggal 11 Nopember 2015, jam 09.30 wib.
} 
society) dan pihak swasta atau pasar atau dunia usaha (business entity). Ilustrasi untuk ketiga komponen tersebut dapat digambarakan sebagai berikut:

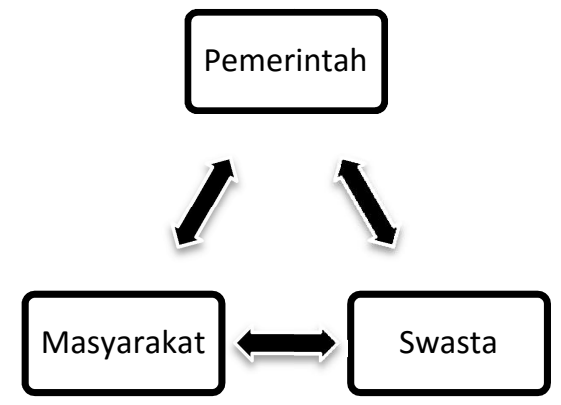

Ketiga komponen tersebut diharapkan bekerja secara simultan untuk memenuhi kebutuhan masing-masing dengan prinsip take and give. Dalam pelaksanaannya, setiap komponen diberikan kebebasan untuk mengeksplorasi dan mengelola sumber daya ekonomi yang tersedia untuk didistribusikan kepada yang membutuhkan. Prinsip tersebut yang kita kenal dengan istilah liberalisme atau neoliberalisme, yaitu kebebasan mengeksplorasi setiap sumberdaya (resources) yang ada untuk didistribusikan atau dipasarkan.

Mengingat eksplorasi dan pengelolaan tersebut dibutuhkan modal yang cuku besar (lebih-lebih jika hal tersebut terkait dengan publik yang luas), maka dipastikan harus ada "kompensasi" yang dianggap menguntungkan, yaitu bahwa seluruh aktifitas pendistribusian sumber daya ekonomi (barang dan jasa) didasarkan pada orientasi laba (profit orientation). Sebagai bagian komponen dalam sistem demokrasi saat ini, kita tentu dapat merasakan hal tersebut. Sebagaimana yang kita saksikan bahwa distribusi sumber daya ekonomi bahkan pelayanan publik dilaksanakan tidak hanya oleh pemerintah atau negara, tetapi juga sektor bisnis atau swasta maupun komunitas-komunitas dalam masyarakat.

Secara pasti, pemerintah tidak lagi memonopoli peran dan fungsinya dalam memenuhi kebutuhan publik atau masyarakatnya, tetapi membagi tanggung jawab pelayanan publik dengan pihak swasta. Harapannya adalah terwujudnya layanan publik yang baik dan memuaskan. Namun layanan publik yang baik dan memuaskan tersebut harus dibayar dengan cost yang juga 'memuaskan' (baca: mahal).

Selanjutnya, peranan sektor swasta dalam pelayanan publik menjadikan pergeseran peranan pemerintah. Pemerintah bukan lagi penanggungjawab utama dalam pelayanan publik karena sebagian dibebaskan untuk dikelola swasta dengan alasan menciptakan kepuasan. Sebagai bagian dari publik tentunya kita bisa menjadi saksi hidup yang fair bahwa pembaruan dalam pemerintahan sistem demokrasi adalah perubahan fungsi pemerintahan sebagai pelayan publik menjadi entitas bisnis.

Masyarakat diposisikan sebagai pelanggan (customer) layanan publik; dengan membayar pajak maka akan mendapatkan hak dan layanan dalam kuantitas dan kualitas tertentu. Paradigma business atau untung-rugi ini menjadi prinsip tidak hanya dalam aktivitas perdagangan sesungguhnya, tetapi juga dalam aktivitas birokrasi atau pelayanan publik. Untung-rugi bukan hanya 
dilakukan oleh pedagang tetapi juga aparatur negara baik di lembaga eksekutif, yudikatif dan legislatif. Oleh karena itu tidak mengherankan jika cara kerja partai politik pun dibangun atas dasar untung-rugi dengan berbagai manuver politik transaksional. Rakyat akan dilayani dan dibela jika memberikan keuntungan bagi partai politiknya, sebaliknya rakyat jangan pernah berharap didengarkan aspirasi dan keluhannya jika tidak menguntungkan partai. Itulah sesungguhnya konsep good governance yang ditawarkan demokrasi kepada rakyat, yang tidak lain merupakan cara berfikir materialisme atau kapitalisme. Maka bisa dipastikan bahwa good governance ala demokrasi hanya akan jalan ditempat alias quo vadis.

Good governance tidak akan pernah terealisasi dalam sitem demokrasi, yang terjadi justru dichotomy governance, yaitu kasta-kasta dalam pengelolaan dan pelayanan publik. Dimana rakyat akan dilayani berdasarkan uang dan nilai material yang mereka miliki. Ada pelayanan spesial bagi orang borjuis dan pelayanan asal-asalan bagi kaum proletar. Pejabat dan pengusaha kompradornya bebas mengekploitasi sumberdaya ekonomi sesukanya, sementara rakyat jelata harus puas dengan mengais sisanya.

\section{Kegagalan Good Governance ala Sistem Demokrasi}

Jika kita analisis, setidaknya ada 3 (tiga) faktor yang menyebabkan kegagalan atau setidaknya quo vadis good governance dalam sistem demokrasi, yaitu: Pertama, kesalahan paradigma terhadap nilai kepuasan. Yaitu memandang bahwa nilai kepuasan hanya diukur dengan aspek-aspek yang bersifat materi, sehingga jumlah dan kualitas harta kekayaan yang dijadikan fokus utama. Produktifitas individu dan masyarakat diarahkan untuk menghasilkan bendabenda pemuas kebutuhan (goods) kemudian hasilnya diapresiasi dengan sejumlah fasilitas dan kenikmatan hidup duniawi.

Kedua, distorsi terhadap peranan dan fungsi negara atau pemerintah. Menyetarakan kedudukan pemerintah dengan busines entity dalam hal fungsi dan peranannya dalam melayani masyarakat jelas sebuah kezhaliman karena negara akan melayani rakyat setengah hati, sebab memandang rakyat bukan lagi sebagai anak-anak yang harus diasuh melainkan sebagai pelanggan yang bisa diambil keuntungan dari mereka. Maka pelayanan publik pun berubah menjadi transaksi bisnis. Hal yang harus kita ingat bahwa setiap individu memiliki potensi yang berbeda. Nah, jika seluruh fasilitas publik harus diukur dengan cost yang dikeluarkan, dipastikan terdapat sejumlah rakyat yang akan tidak mendapatkan fasilitas publik yang dibutuhkannya.

Ketiga, rendahnya pemahaman terhadap jati diri manusia yang sesungguhnya. Akal manusia semestinya digunakan untuk berpikir secara mendalam tentang keberadaan manusia di dunia. Dan jika itu kita lakukan, maka kita akan mendapati keterbatasan manusia (secara akal dan fisik) sehingga dibutuhkan hubungan vertikal (transedental connection) untuk menyelesaikan berbagai persoalan manusia dan kehidupan secara universal. Ini sebuah keniscayaan, karena pencipta dunia, alam semesta, manusia dan kehidupan hanya satu, yaitu al-khaliq Allah SWT. Memaksakan diri untuk menggunakan aturan manusia seperti demokrasi, kapitalisme, KUHP, BW (burgerlijk wetboek) dan 
hukum manusia lainnya akan menjerumuskan manusia itu sendiri ke dalam lingkaran setan problem kehidupan yang tidak akan berkesudahan. Kita harus berani mengimplementasikan hukum-hukum Allah SWT sebagai main dealer-nya manusia dan kehidupan.

\section{Good Governance dalam Islam}

Berbeda halnya jika kita menggunakan aturan sang pencipta Allah SWT yang tertera dalam Al-Qur'an dan telah dicontohkan praktiknya oleh sosok manusia mulia Muhammad SAW. Setidaknya ketiga faktor penyebab stagnasi atau quo vadis good governance dalam sistem demokrasi tidak akan kita alami.

Pertama, Islam memandang manusia secara komprehensif yaitu dari aspek materi dan nonmateri (spiritual). Banyak sekali ayat-ayat dan hadits-hadits yang menjelaskan bahwa harta dan kekayaan bukanlah tujuan, melainkan sebagai sarana untuk beribadah kepada Allah SWT. Islam juga mengapresiasi manusia berdasarkan kemuliaannya dan peranannya dalam menciptakan kemashlahatan bagi manusia yang lain, sebab tujuan manusia hidup di dunia adalah untuk beribadah kepada Allah SWT. Dengan prinsip-prinsip diatas, maka eksploitasi terhdap manusia (tenaga kerja) dan eksplorasi terhadap sumberdaya ekonomi akan dilakukan sesuai dengan kebutuhan serta meminimalisasi terkonsentrasinya harta dan kekayaan pada segelintir orang.

Kedua, Islam melandaskan setiap aktivitas manusia bukan pada orientasi manfaat atau untung-rugi saja, melainkan keridloan Allah SWT. Sehingga segala sesuatu akan ditimbang dan diukur berdasarkan prosedur dan cara-cara yang ditetapkan oleh tasyri' atau hukum syara'. Seperti halnya tugas dan aktivitas pemimpin negara atau pemerintahan, keberadaan mereka adalah benar-benar sebagai pelayan bagi terpenuhinya kebutuhan publik berupa kesejahteraan, keamanan, pendidikan yang baik, kesehatan dan peribadatan. Dalam prakteknya pemerintah dalam Islam akan melakukan pelayanan tersebut tanpa menghitunghitung laba atau rugi. Seluruh potensi sumber daya ekonomi yang merupakan milik publik akan dimaksimalkan peruntukannya untuk masyarakat. Dalam hal ini terdapat perbedaan paradigma yang jelas mengenai fungsi pemerintah dan entitas usaha atau bisnis.

Sebagai gambaran hal tersebut, Rasulullah SAW bersabda dari riwayat anNasa'i dan Ibn Hibban: "ana aula bil mu'miniina min anfusihim, man taroka maalan fa lil ahliha, wa man taroka daynan au dhiyaa'an fa ilayya wa 'alayya". Artinya: "aku lebih utama dibandingkan orang-orang beriman daripada diri mereka sendiri, siapa yang meninggalkan harta maka bagi keluarganya dan barangsiapa yang meninggalkan hutang atau tanggungan keluarga yang terlantar, maka datanglah kepadaku dan menjadi kewajibanku".

Faktor yang kedua ini berimplikasi pada keniscayaan pelayanan pemimpin terhadap masyarakat secara pure tanpa paradigma untung-rugi. Sebagaimana sabda Rasulullah SAW dalam shahih Bukhari no. 2232:

فالإمام راع وهو مسؤل عن رعيته

"Imam (kepala Negara) adalah pemimpin yang akan diminta pertanggung jawaban atas rakyatnya." 
Ketiga, keyakinan terhadap eksistensi Allah SWT (Iman) telah memunculkan konsekuensi logis berupa terikatnya umat Islam terhadap hukum syara', sebab Allah SWT telah memaklumatkan bahwa hukum terbaik adalah hukum yang berasal dari sisi-Nya, bukan hukum manusia. Dengan bekal keimanan semacam ini, kita akan melihat bahwa kehidupan dunia ini sangat ringan dibandingkan kekuasaan Allah SWT. Fokus kita tidak hanya di bumi melainkan juga mengarah ke langit. Sehingga setiap menemukan persoalan serumit apapun kita akan mengatakan bahwa tak ada yang tidak dapat diselesaikan jika Allah SWT berkehendak. Semangat hidup terus menggelora menuju terciptanya tatanan kehidupan yang baik bagi seluruh manusia.

\section{Mengapa Islamic Good Governance sangat Dibutuhkan?}

Beberapa alasan yang mengokohkan pentingnya penerapan Islamic Good Governance adalah:

1. Setiap aktivitas kita dalam memenuhi kebutuhan atau hajat sebagai manusia (hamba Allah) merupakan bagian dari perbuatan yang akan dimintai pertanggungjawaban kelak di akhirat;

2. Setiap aktivitas manusia dalam perspektif Islam tidak hanya diukur dalam aspek kuantitas atau volume pencapaian tetapi juga diatur dan dibatasi dalam cara perolehan dan pendayagunaannya;

3. Setiap komponen dalam kehidupan berbangsa dan bernegara memiliki tugas tanggungjawab yang telah diatur tugas dan weweanga masing-masing. Namun pada hakikatnya setiap komponen masyarakat adalah individu yang akan bertanggungjawab pada dirinya sendiri, tanggungjawab kepada lingkungan (masyarakat), dan tanggungjawab kepada Allah SWT;

4. Pengamatan terhadap fakta kesenjangan ekonomi, angka kemiskinan, tingginya jumlah pengangguran, penyakit sosial (kriminalitas, pornografi, pornoaksi, narkoba, prilaku asusial, dan lain sebagainya), serta dekadensi moral (moral hazard) dalam bentuk prilaku korupsi, manipulasi, money politic, dan sogok/suap. Fakta tersebut menunjukkan kegagalan good governance ala sistem demokrasi sehingga dibutuhkan model alternatif.

5. Kesuksesan good governance perspektif Islam dapat ditujukkan dalam fakta historis. Setidaknya berikut penuturan sejarawan dunia yang ditulis secara objektif:

a. Sebagaimana ditulis Dr. Gordon S. Matthews: “...growth of regional and trans-regional trade, and of urban manufacturing, produced new level of prosperity accross the city landscape" 6 Bahwasanya pada masa kejayaan Islam perdagangan tumbuh dalam lintas daerah, bahkan industri yang dikembangkan masyarakat perkotaan mampu menciptakan kemakmuran yang lebih merata.

\footnotetext{
${ }^{6}$ Matthews S. Gordon, The Rise of Islam, (London: Greenwood Press), 2005.
} 
b. Jonathan Bloom menuliskan: "In the Islamic lands, not only muslims but also christian and jews enjoyed a good life".7 Saat Eropa berada dalam masa kegelapan (dark age) negeri-negeri Islam dalam naungan Khilafah Islamiyah telah mengukuhkan terwujudnya civil society yang dirintis oleh Rasulullah SAW., sejak di Madinah. Disebutkan tidak hanya umat Islam, tetapi umat Kristen dan umat Yahudi hidup dalam suasana yang harmonis.

c. Di bidang pembangunan pendidikan sejarahwan Karen Armstrong menyebutkan: "Moslem scholars made more scientific discoveries during this time than in the whole of previously recorded history". ${ }^{8}$ Bahwa tidak bisa dipungkiri peranan intelektual Muslim dalam bidang penemuan ilmiah paling produktif sepanjang catatan sejarah.

d. Secara objektif Gaston Wiet juga menuliskan: "People of the west should publicly express their gratitude to the scholars of the Abbasid period, who were known and appreciated in Europe during the middle age". 9

Demikian beberapa catatan sejarah yang secara objektif menggambarkan keberhasilan Islam dalam membangun dan menciptakan good governance di semua aspek kehidupan: ekonomi, sosial, politik, hukum, dan keamanan. Tulisan Will Durant, dalam The Story of Civilization, vol. XIII, p. 151;

"Para Khalifah telah memberikan keamanan kepada manusia hingga batas yang luar biasa besarnya bagi kehidupan dan kerja keras mereka. Para Khalifah itu juga telah menyediakan berbagai peluang untuk siapapun yang memerlukannya dan memeberikan kesejahteraan selama berabad-abad dalam wilayah yang sangat luas. Fenomena seperti itu belum pernah tercatat (dalam sejarah) setelah zaman mereka."10

\section{Peran Strategis Pendidikan Islam}

Pendidikan dalam Islam merupakan sesuatu yang sifatnya urgent. Sehingga dalam sumber hukum Islam banyak kita temukan anjuran dan perintah untuk menuntut ilmu, seperti yang tercantum dalam Al-Qur'an surat Az-Zumar ayat 9:

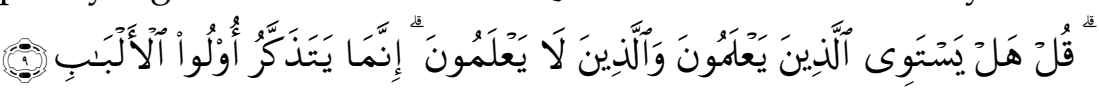

"Katakanlah: "Adakah sama orang-orang yang mengetahui dengan orang-orang yang tidak mengetahui?" Sesungguhnya orang yang berakallah yang dapat menerima pelajaran."

Menurut Abdurrahman Al-Baghdady, beberapa tujuan pendidikan Islam antara lain: ${ }^{11}$

\footnotetext{
7 Jonathan Bloom \& Sheila Blair, Islam- A Thousand Years of Faith and Power, (London: Yale University Press), 2002.

${ }^{8}$ Karen Armstrong, Islam A Short Story (London: Phoenix), 2002.

9 Gaston Wiet, Baghdad: Metropolis of the Abbasid Caliphate (London: University of Oklahoma Press), 1971.

10 Arim Nasim (Dr., Msi. Ak), Ekonomi Islam: Mensejahterakan Seluruh Rakyat, al-wa'ie no. 130, Juni 2011, 29.

11 Abdurrahman Al-Baghdady, Sistem Pendidikan di Masa Khilafah Islam, (Bangil: Penerbit Al-Izzah, 1996), 25-28.
} 
1. Membekali akal dengan pemikiran dan ide-ide yang sehat

2. Memberikan pemahaman yang benar mengenai persolan aqidah, hukum, dan pengetahuan berdasarkan perspektif Islam (ilmu fiqh, tafsir, dan hadits)

3. Menciptakan manusia yang berkepribadian Islam, yaitu meletakkan segala tingkah laku dan perbuatannya berdasarkan Al-Qur'an dan As-Sunnah

4. Membentuk pribadi yang mencintai Allah SWT dan Rasul-Nya melebihi kecintaanya kepada keluarga, kerabat, dan hartanya

5. Membekali manusia dengan life skill dan pengetahuan seperti ilmu alam, ilmu kimia, matematika, teknolgi, perindustrian, perdagangan, pelayaran, pertanian, kedokteran, dan lain sebagainya yang didasarkan (berazas) kepada aqidah Islam.

Dalam tinjauan filosofis dan aksiologis, pendidikan memegang peranan penting dari tujuan hidup yang hendak dicapai oleh manusia dalam menempuh kehidupan sehari-hari. Secara umum, penyelenggaraan kegiatan pendidikan bertujuan untuk: 12

1. Membantu pembentukan kepribadian;

2. Melakukan pembinaan moral;

3. Menumbuhkan dan mengembangkan keimanan dan ketakwaan siswa.

Berdasarkan uraian di atas, tampak jelas bahwa pendidikan hakikatnya merupakan proses untuk menciptakan sumberdaya manusia yang memiliki kepribadian atau karakter, bukan sekedar sumberdaya manusia yang pragmatis, namun juga concern terhadap nilai-nilai nonmaterial (spiritual). Sehingga kesuksesan tujuan pendidikan akan memudahkan terwujudnya good governance dalam kehidupan berbangsa dan bernegara.

Oleh karena itu peranan strategis pendidikan Islam dalam mewujudkan Islamic Good Governance (IGG) dapat dirinci sebagai berikut:

1. Sebagai media atau wadah internalisasi mengenai:

a. Urgensi mewujudkan IGG dalam kehidupan berbangsa dan bernegara;

b. Rule model IGG yang telah dicontohkan oleh Rasulullah SAW dan generasi setelahnya;

c. Implementasi rule model IGG yang ideal dalam konteks kekinian dan aplikatif.

Ketiga hal tersebut sangat relevan dilakukan oleh institusi pendidikan Islam, mengingat lembaga pendidikan Islam merupakan tempat dan media pemebelajaran yang bertugas untuk mengkaji dan mengeksplorasi nilai-nilai Islam dan mengaplikasikannya dalam kehidupan bermasyarakat, berbangsa, dan bernegara.

2. Menciptakan sumberdaya manusia yang relevan bagi terwujudnya IGG. SDM yang relevan bagi terwujudnya IGG adalah SDM yang memiliki pengetahuan Islam yang cukup, memiliki kapabilitas, karakter, dan integritas. SDM tersebut merupakan tanggungjawab besar institusi pendidikan Islam. Untuk

12 Kompri, Manajemen Pendidikan, (Yogyakarta: Ar Ruzz Media, 2015), 17. 
merealisasikannya, institusi pendidikan Islam harus menempuh tiga tahapan antara lain: ${ }^{13}$

a. Persiapan, dengan menyiapkan dan menyediakan tim untuk membentuk sistem yang efektif;

b. Pengembangan sistem, melalui pelatihan, motivasi, dan monitoring atau kontrol;

c. Implementasi sistem, melalui pembelajaran di dunia nyata dan experiential learning.

Ketiga langkah tersebut diharapkan mampu menyiapkan SDM yang mumpuni (expert) bagi terwujudnya IGG.

3. Menjadi prototipe atau miniatur visualisasi IGG. Dalam hal ini, institusi pendidikan Islam yang pada prinsipnya merupakan entitas nirlaba harus mampu menjadi uswah bagi implementasi IGG. Berdasarkan pendekatan good corporate governance (GCG), setidaknya ada 5 (lima) prinsip dasar yang harus diterapkan dalam dunia pendidikan secara umum: ${ }^{14}$

a. Transparency, yaitu setiap partisipan dalam institusi pendidikan harus menyampaikan informasi yang materialnya sesuai dengan substansinya;

b. Accountability, kewajiban partisipan institusi pendidikan untuk mempertanggungjawabkan amanah yang diterima sesuai dengan hukum, peraturan, standar moral/ etika, dan best paractices;

c. Responsiveness, bahawa dalam menjalankan fungsinya setiap partisipan harus tanggap terhadap perubahan, masukan, dan feedback dari stakeholder;

d. Independency, setiap partisipan harus mampu menghindari berbagai macam conflict of interst;

e. Fairness, setiap partisipan harus menjalankan fungsinya dengan sikapsikap yang adil dan bijaksana.

\section{Penutup}

Jika kita amati kelima prinsip dasar tersebut, dapat disimpulkan bahwa tanggungjawab institusi pendidikan Islam tidak akan jauh berbeda, yaitu bagaimana mengimplementasikan prinsip-prinsip dasar pendidikan (tarbiyah) yang telah dilakukan oleh Rasulullah SAW dalam menciptakan visualisasi IGG yaitu fathonah, amanah, siddiq, dan tabligh. Sehingga sangat rasional jika institusi pendidikan Islam saat ini juga harus mampu menjadi prototipe implementasi IGG dalam kehidupan modern saat ini.

\section{DAFTAR PUSTAKA}

Abdurrahman Al-Baghdady, Sistem Pendidikan di Masa Khilafah Islam, Bangil: Penerbit Al-Izzah, 1996.

\footnotetext{
${ }_{13}$ Aminatul Zahroh, Total Quality Management; Teori \& Praktik Manajemen Untuk Mendongkrak Mutu Pendidikan, (Yogyakarta: Arruzz Media, 2014), 95.

14 Sony Warsono, dkk., CGCG UGM's Corporate Governance Rating Model, (Yogyakarta: FEB UGM, 2010), 22.
} 
Abidari Rosidi dan Anggraeni Fajriani, Reinventing Government, Yogyakarta: Andi Offset, 2014.

Aminatul Zahroh, Total Quality Management; Teori \& Praktik Manajemen Untuk Mendongkrak Mutu Pendidikan, Yogyakarta: Arruzz Media, 2014.

Arim Nasim (Dr., Msi. Ak), Ekonomi Islam: Mensejahterakan Seluruh Rakyat, al-Wa'ie no. 130, Juni 2011, 29.

Kompri, Manajemen Pendidikan, Yogyakarta: Ar Ruzz Media, 2015.

Rahmat Kurnia (Dr., M.Si), Peran Islam terhadap Peradaban Dunia, Hand Out Konferensi Internasional (JICMI), Jakarta, 2013.

Sony Warsono, dkk., CGCG UGM's Corporate Governance Rating Model, Yogyakarta: FEB UGM, 2010.

Sumarto Hetifa, Sj, Inovasi, Partisipasi, dan Good Governance, Bandung: Yayasan Obor Indonesia, 2003.

Yap Kioe Sheng, Chief Poverty Reduction Section UNESCAP, Good Governance, www.unescap.org, diakses tanggal 11 Nopember 2015, jam 09.30 wib. 